\title{
Child Abuse and Children's Strategies to Cope with Abuse
}

\author{
Devrim Erginsoy Osmanoğlu ${ }^{1, *}$ \\ ${ }^{1}$ Department of Educational Sciences, Faculty of Education, Kafkas University, Turkey \\ *Correspondence: Department of Educational Sciences, Faculty of Education, Kafkas University, Turkey. E-mail: \\ erginsoy@hotmail.com
}

Received: November 14, 2018

Accepted: December 12, 2018 Online Published: January 18, 2019

doi:10.5430/wje.v9n1p28

URL: https://doi.org/10.5430/wje.v9n1p28

\begin{abstract}
Abuse refers to any form of physical, emotional, sexual and economic maltreatment that actually damages the child's health, life, development and / or dignity. The prevention of abuse will be possible through the recognition of abuse and abuser by the child and strengthening of the active strategies used by the child to act against them. In line with the general purpose of the study, answer to the questions "Which age groups from among the elementary school and secondary school students are under the risk in terms of being abused?", "Which type of abuse is frequently experienced by the child?", "Who are the abusers?", "What are the strategies used by the child abused to cope with the incidence of abuse?" were sought. An opinion form consisted of 8 questions was used in the current research. The data collected from a total of 616 students were subjected to content analysis. According to the results obtained $75 \%$ of the children from different age groups were found to have been subject to abuse and all the age groups were most abused by their peers, followed by family members and relatives.
\end{abstract}

Keywords: abuse, child abuse, types of abuse, abuse-coping strategies

\section{Introduction}

Cultural factors determine our rules of life as well as generally accepted principles of child rearing and child care in the society. Parenting practices of different cultures also vary. However, as meeting basic needs such as receiving healthy care, being approved and loved in childhood years is necessary for the child to maintain healthy and adaptable life, all cultures agree on the idea that the child should never be allowed to be abused and neglected (WHO, 2018). The World Health Organization (WHO) defines abuse as any form of physical, emotional, sexual and economic maltreatment that causes actual or potential harm to the child's health, life, development and / or dignity (Mavi Aydoğdu \& Özsoy, 2017). The effects of child abuse and neglect on children's physical, psychological, cognitive and behavioral development may be devastating. Physical abuse can lead to minor injuries, serious brain damage or even death. Psychological consequences extend from chronic low self-esteem to severe dissociative conditions. The cognitive effects of abuse range from attention problems and learning disorders to serious organic brain syndromes. The results of behavioral abuse range from weak peer relations to extraordinary violent behaviors. Thus, the consequences of abuse and neglect affect the victims themselves and the society in which they live (Crosson-Tower, 1993).

In 1999, the WHO conducted a study to construct all forms of child abuse and neglect. This study included many topics such as physical and / or emotional maltreatment, sexual abuse, neglect or negligence, commercial or other exploitations and relationship of trust or power. Experts have stated that child maltreatment is mostly done in physical, sexual and emotional areas. By adding negligence to these, which is as harmful as abuse for child health, they have classified them under four main headings (WHO, 2018). These headings are; 1. Physical abuse, 2. Emotional abuse, 3. Sexual abuse and 4. Negligence.

Physical abuse; giving physical harm to the child through acts committed by parent, caregiver or another person on purpose such as hitting, kicking, biting, shaking, pushing, strangling with an object or a belt, stabbing or burning.

Sexual Abuse; CAPTA (Child Abuse Prevention and Treatment Organization) has defined sexual abuse as a child's exploitation for sexual purposes, persuasion, encouragement or coercion to perform obscene conduct with another person or exploitation through rape, prostitution or the production of pornographic materials and simulations (Child Welfare Information Gateway, 2013). According to the World Health Organization, sexual abuse is the 
inclusion of a child in a sexual activity that the child cannot fully understand, give consent for, is not developmentally ready for and that is against laws and social norms of the society. Sexual abuse is a conduct occurring between a child and an adult or another child who is older than him/her, leading to the sexual satisfaction of the abuser using the relationship of responsibility, trust or power (Karaca, 2018).

Emotional Abuse; They are behavioral patterns negatively affecting a child's emotional development or self-esteem through continuous criticism, threat, rejection, deprivation of love and support. They emerge as a result of child's feelings and opinions not being taken seriously, his/her being ridiculed or humiliated and being left devoid of activities through which he/she can actualize himself/herself. Emotional abuse is often difficult to prove and therefore child protection services may not be useful most of the time. It is mostly caused by unconsciousness and is masked by different cultural behaviors. For example, girls are less respected than boys, which emerges as a type of emotional abuse (Karaca,2018; Child Welfare Information Gateway, 2013). While all kinds of abuse cause destructive effects, it has been determined that the child who is exposed to emotional abuse experience many problems such as depression, anxiety, personality disorders and aggression and that his/her mental and physical development, academic performance, IQ score, memory, learning capacity and brain volume has been adversely affected (Hart \& Rubia, 2012)..

Negligence; The failure of the child's parent or care giver to meet the basic needs of the child. In addition, not following health care recommendations for the child, the child's not receiving proper health service, not receiving enough food or starving, the child's exposure to medicine, insufficient supervision, deprivation, renouncing, poor hygiene, neglect of education, lack of protection against environmental hazards, lack of provision of dressing or care are also named as negligence (WHO, 2018).

For child abuse to occur, three factors should exist together: suitable father-mother, suitable child, suitable time (crisis period). The fourth factor is domestic violence. Abusive parents generally take their personal satisfaction superior to their children, see their children as means through which they can meet their needs, have unrealistic expectations of their children, are strict and cannot control their emotions (Kara et al., 2004). In many studies conducted to determine the individuals responsible for all forms of abuse of children, $77 \%$ of them were found to be family members, 11 of them were found to be other relatives, $5 \%$ of them were found to be individuals having no connection with the care of the child and $2 \%$ of them were found to be individuals responsible for the care of the child. It is known that $60 \%-70 \%$ of cases of sexual abuse are carried out by people who are known and trusted by the child, such as parents, relatives, teachers, neighbors or authority figures (Taner \& Gökler, 2004; Jain, 1999, Kara et al., 2004). Elliott, Browne, and Kilcoyne (1995) also found that children who have family problems, who are alone and not self-confident are more sexually abused.

For the protection of the spiritual health of the child who feels under threat due to physical, emotional or sexual abuse, prevention of abuse is of vital importance. As it takes too much time to identify the abuser and to distance $\mathrm{him} / \mathrm{her}$ from the child and as it is even impossible to identify sometimes, any type of abuse can be prevented by developing the child's ability to cope with adverse situations. The child's ability to protect herself against abuse and abuser will prevent many incidents (Compas et al., 2014). The individual's ability to overcome the anxiety brought about by the perceived threat and the individual's seeking solutions to situations that cause stress and anxiety is defined as the coping strategy. Many scientists such as Lazarus have investigated the ways through which individuals cope with negative life events and come up with classifications such as 1) Problem-oriented strategies in which the person acts to correct the situation 2) Emotion-focused strategies (avoidant-passive) in which the individual does not take any action, just removes the situation that creates anxiety from his/her conscious (cited in Pehlivan, 1994; Burger, 2006; Karabulutlu, 2010). Burger (2006) made a more detailed classification and offered the following classification: active cognitive strategies that are used to fight against the problem, active behavioral strategies involving directly getting into action and avoidant strategies based on the avoidance of the problem; that is, pretending as if there was no problem.

According to Burger, behavioral patterns displayed by individuals using active cognitive (emotion-focused) strategies are as follows;

- Questioning the correctness and wrongness of an opinion,

- Praying to be stronger,

- Facing the situation

- Trying to see the positive sides of an event,

- Analyzing the possible ways of finding solutions to a problem, 
- Capitalizing on experiences,

- Seizing the day,

- Self-commanding to make the person himself/herself feel better,

- Learning from mistakes,

- Admitting that there is nothing to do when all the alternatives have been used up,

- Trying to understand the event thoroughly by making its continuous simulation in the mind,

- Dreaming about an incidence or environment that will help the individual distance himself/herself from negative feelings and thoughts.

Behavioral patterns displayed by individuals using active behavioral (problem-orinted) strategies;

- Trying of obtain more information about the situation,

- Doing relaxing/breathing exercises,

- Instead of obsessively pondering about the issue, doing different activities,

- Talking to relatives about the problem,

- Talking to an expert (doctor, lawyer, religious man etc.),

- Doing an action plan and following it,

- Trying harder in case of failure,

- Abreacting,

- Seeking help from individuals or groups having had the same experiences,

- Deriving a positive outcome from the situation and reaching a compromise,

- Trying to reduce the tension by doing physical activities such as doing sports or yoga, washing car, dancing.

Behavioral patterns displayed by individuals using avoidant strategies;

- Taking out on somebody in response to situations causing anger or anxiety (changing direction)

- Not sharing feelings with anybody,

- Staying away from people in general,

- Rejecting to believe in others' explanations,

- Trying to reduce the tension by using more tranquilizers or drugs,

- Trying to reduce the tension of anxiety by eating more,

- Sleeping more,

- Doing uncontrolled shopping,

- Denying negative feelings and/or trying to forget (Burger, 2006; Aydın \& İmamoğlu, 2001).

The prevention of abuse will be possible through the strengthening of the active strategies requiring the child to act to solve the problem or to fight against the problem. This is the golden key to find a complete solution to any problem. It is an undeniable fact that regardless of the type of abuse and neglect, it causes many destructive effects on the child. Child abuse is a serious global health problem that needs to be urgently solved. Given that fact, in line with the general purpose of the current study, answers to the following questions were sought:

1. Which age group $(7,8,9,10,11,12,13$ and 14 year olds) from elementary and middle school students is under the risk of being subjected to abuse?

2. Do the cases of exposure to abuse and neglect vary significantly depending on gender?

3. What are the behaviors seen to be the expression of love by the child?

4. What is the type of love shown to the child?

5. Which type of abuse does the child experience more frequently?

6. Who are abusers?

7. What are the strategies used by the child to cope with abuse? 


\section{Methodology}

\subsection{Research Model}

The current study was conducted on the basis of the field survey method used to explore events and phenomenon in their natural environments.

\subsection{Study Group}

A total of 616 students (357 girls and 319 boys) attending $1^{\text {st }}, 2^{\text {nd }}, 3^{\text {rd }}, 4^{\text {th }}, 5^{\text {th }}, 6^{\text {th }}, 7^{\text {th }}$ and $8^{\text {th }}$ grades $(7,8,9,10,11,12$, 13 and 14 years old) of 3 elementary and middle schools located in the cities of Kars, Van and Diyarbakır participated in the study.

\subsection{Data Collection Tool}

The current study used an opinion form consisted of 8 questions. These questions are; 1) How do people show their love to each other? 2) Through which behaviors do people loving you show their love to you? 3) Do you think that some people exhibit negative behaviors against you? 4) Which behaviors of these people make you sad? 5) Which behaviors of these people make you embarrassed? 6) Which behaviors of these people hurt you? 7) If there are people whose behaviors that make you sad, embarrassed and hurt you are repeated, who are these people? 8) What do you do when you are maltreated?" From the responses given to these questions, it was aimed to determine the types of abuse to which children are exposed and the strategies they use to cope with abuse.

\subsection{Data Collection and Analysis}

In an environment where 7 and 8 year old children's attention would not be distracted, the questions were directly asked to the 7 and 8 year old children and their responses were directly recorded by the implementers. On the other hand, the list of the questions was given to the children who can read and write and they were asked to answer these questions. The data collected in this way from elementary and middle school students were subjected to content analysis. Each researcher read the texts written by the students and coded the data found in the texts under the headings of physical, sexual, emotional abuse and neglect, which are defined and agreed on in the literature. In addition, the strategies used by the children abused were examined under the coping categories of active-cognitive, active-behavioral and avoidant. The emerging categories of abuse and emotional states are presented together with their frequencies. After a certain interval, the same operation was repeated. In order to confirm whether the codes given under the relevant conceptual category represent this conceptual category, the codes of two independent researchers and their categories of codes were compared and agreement was reached. In descriptive analyses, in order to reflect the opinions of the interviewees in a striking manner, direct quotations are given (Ylldirım and Şimşek, 2011). Thus, in the current study, the children's responses were supported with direct quotations.

\section{Results}

In order to determine which behaviors the children see as an expression of love, they were asked the question "How do people show their love to each other?" and the responses they gave to other questions were classified under the categories of physical, emotional and sexual and analyzed. The children's responses given within the context of this question were directly quoted. The letter in the parenthesis (B or G) stands for the gender of the child and the number next to it represents the code number of the child.

Table 1. Distribution of the Behaviors Seen as the Expression of Love

\begin{tabular}{lccccccc}
\hline $\begin{array}{l}\text { Age } \\
\text { Group }\end{array}$ & \multicolumn{5}{c}{ Girls } & \multicolumn{5}{c}{ Boys } & \\
\cline { 2 - 7 } 7 age & Physical & Emotional & Sexual & Physical & Emotional & Sexual & Total \\
\hline 8 age & 1 & 1 & 0 & 0 & 3 & 0 & 5 \\
9 age & 1 & 17 & 0 & 0 & 24 & 0 & 42 \\
10 age & 11 & 89 & 0 & 12 & 58 & 0 & 175 \\
11 age & 6 & 157 & 0 & 49 & 44 & 0 & 261 \\
12 age & 4 & 44 & 0 & 10 & 77 & 0 & 236 \\
13 age & 4 & 40 & 0 & 1 & 40 & 0 & 89 \\
14 age & 8 & 36 & 0 & 7 & 34 & 0 & 85 \\
Total & 51 & 527 & 0 & 86 & 329 & 0 & 100 \\
\hline
\end{tabular}


As can be seen in the findings, both boys and girls stated that the most common expression of love is emotional feedbacks.

Emotional category: "By talking to him/her pleasantly.(G15)", "By showing interest in the other." (G21), By helping him/her." (B51)

Physical category: "You show your love by hugging." (G73),"You kiss her/him." (B8), "You protect him/her against dangers. "(B34

Table 2. Distribution of the Ways of Children's Being Loved

\begin{tabular}{lccccccc}
\hline & \multicolumn{9}{c}{ Girl } & & \multicolumn{3}{c}{ Boy } & \\
\cline { 2 - 6 } Age Group & Physical & Emotional & Sexual & Physical & Emotional & Sexual & Total \\
\hline 7 age & 1 & 1 & 0 & 0 & 3 & 0 & 5 \\
8 age & 0 & 20 & 0 & 0 & 22 & 0 & 42 \\
9 age & 11 & 77 & 0 & 9 & 59 & 0 & 156 \\
10 age & 9 & 147 & 0 & 5 & 114 & 0 & 275 \\
11 age & 3 & 116 & 0 & 6 & 76 & 0 & 201 \\
12 age & 2 & 53 & 0 & 0 & 42 & 0 & 97 \\
13 age & 1 & 34 & 0 & 7 & 22 & 0 & 64 \\
14 age & 0 & 53 & 0 & 8 & 51 & 0 & 112 \\
Total & 27 & 501 & 0 & 35 & 389 & 0 & 952 \\
\hline
\end{tabular}

When the children's responses to the question "Through which behaviors do the people loving you show their love to you?" asked to find the ways of children's being loved are examined, it is seen that both girls and boys are loved most through emotional feedbacks. Another remarkable finding is that boys in the age group of 10 stated that they are physically loved more than the children in the other age groups.

Emotional category: "They play with me." (G28)", "They protect me." (G85), "They show their love by treating me in a friendly manner" (B67) me." (B25)

Physical category: "They stroke my hair." (G65),". "They say that they love me"(B48), "They laugh at

Table 3. Distribution of Children Abused

\begin{tabular}{lccccc}
\hline Age Group & \multicolumn{2}{c}{ Girls } & \multicolumn{2}{c}{ Boys } & \\
\cline { 2 - 5 } & Yes & No & Yes & No & Total \\
\hline 7 age & 1 & 0 & 2 & 1 & 4 \\
8 age & 14 & 3 & 13 & 7 & 37 \\
9 age & 56 & 28 & 38 & 18 & 140 \\
10 age & 62 & 35 & 58 & 19 & 174 \\
11 age & 56 & 10 & 41 & 19 & 126 \\
12 age & 29 & 6 & 23 & 10 & 68 \\
13 age & 20 & 5 & 19 & 6 & 50 \\
14 age & 23 & 9 & 34 & 11 & 77 \\
Total & 261 & 96 & 228 & 91 & 616 \\
\hline
\end{tabular}

To the question "Do you think that some people exhibit negative behaviors against you?" asked to determine whether the child is abused or not, both boys and girls responded as "Yes" to a great extent. Nearly $75.9 \%$ of the children in the age group of 7 and 8 year olds, $69 \%$ of the children in the age group of 9 year olds, $71.11 \%$ of the children in the age group of 10 year olds, $72 \%$ of the children in the age group of 11 year olds, $76 \%$ of the children in the age groups of 12 and 13 year olds and $74 \%$ of the children in the age group of 14 year olds stated that they had been exposed to any of emotional, physical or sexual abuse. Of the participating girls $(n=357), 73 \%$ stated that they had been exposed to abuse and $47 \%$ of the boys $(n=312)$ stated that they had been exposed to abuse. 
Table 4. Distribution of the Types of Abuse

\begin{tabular}{|c|c|c|c|c|c|c|c|}
\hline \multirow{2}{*}{$\begin{array}{l}\text { Age } \\
\text { Group }\end{array}$} & \multicolumn{3}{|c|}{ Girls } & \multicolumn{3}{|c|}{ Boys } & \multirow[b]{2}{*}{ Total } \\
\hline & Physical & Emotional & Sexual & Physical & Emotional & Sexual & \\
\hline 7 age & 3 & 1 & 0 & 2 & 7 & 0 & 20 \\
\hline 8 age & 12 & 43 & 1 & 13 & 41 & 3 & 110 \\
\hline 9 age & 49 & 170 & 0 & 47 & 112 & 0 & 378 \\
\hline 10 age & 100 & 259 & 0 & 75 & 174 & 0 & 608 \\
\hline 11 age & 86 & 127 & 1 & 34 & 131 & 1 & 380 \\
\hline 12 age & 12 & 106 & 0 & 19 & 91 & 0 & 228 \\
\hline 13 age & 7 & 87 & 0 & 14 & 73 & 0 & 181 \\
\hline 14 age & 4 & 93 & 0 & 27 & 107 & 0 & 221 \\
\hline Total & 273 & 886 & 2 & 231 & 736 & 4 & 2137 \\
\hline
\end{tabular}

When the responses given to the questions "Which behaviors of these people make you sad?", "Which behaviors of these people make you embarrassed?" (emotional and sexual abuse), "Which behaviors of these people hurt you?" (physical and sexual abuse) asked separately to determine the types of abuse to which the children have been exposed are examined, it is seen that they have been most exposed to emotional abuse, followed by physical abuse. There are also some children having stated that they had been exposed to sexual abuse.

Emotional category: "Their humiliating me makes me sad." (G96)", "They are scolding me in front of other people." (G93), "They are talking about my mistakes in the presence of other people" (B69), "They give me a nickname." (B32).

Physical category: "They tear my hair, and slap me." (G6),".They fight and pull out a knife"(B91), "They give the bird"(B82).

Sexual category: "They pull up my skirt." (G102), "My neighbor calls me darling."(G44), "When they show me something embarrassing, I feel embarrassed."(B12), "When they do nasty things, I feel embarrassed"( B59).

Table 5. Distribution of the People Committing the Act of Abuse

\begin{tabular}{lcccccc}
\hline Age Group & Family member & Relative & Friend & Stranger & Teacher & Neighbor \\
\hline 7 age & 1 & 0 & 0 & 2 & 0 & 0 \\
8 age & 0 & 4 & 11 & 1 & 0 & 1 \\
9 age & 4 & 14 & 26 & 3 & 0 & 0 \\
a 10 age & 4 & 2 & 39 & 2 & 1 & 1 \\
: & 71 age & 8 & 34 & 4 & 0 & 0 \\
12 age & 0 & 0 & 9 & 1 & 0 & 0 \\
13 age & 1 & 2 & 8 & 0 & 0 & 0 \\
14 age & 4 & 1 & 16 & 0 & 0 & 0 \\
Total & 21 & 31 & 143 & 13 & 1 & 0 \\
7 age & 0 & 0 & 1 & 2 & 0 & 0 \\
8 age & 2 & 2 & 8 & 4 & 0 & 0 \\
9 age & 3 & 2 & 20 & 1 & 1 & 0 \\
10 age & 6 & 7 & 25 & 5 & 0 & 0 \\
\multirow{2}{0}{11 age } & 2 & 1 & 26 & 2 & 0 & 0 \\
12 age & 1 & 0 & 17 & 0 & 0 & 0 \\
13 age & 0 & 0 & 9 & 0 & 0 & 1 \\
14 age & 0 & 0 & 18 & 3 & 0 & 0 \\
Total & 14 & 12 & 124 & 17 & 1 & 3 \\
\hline
\end{tabular}

According to the responses given to the question "If there are people whose behaviors that make you sad, embarrassed and hurt you are repeated, who are these people?" asked to find who the people committing the act of abuse are, the children are most abused by their friends. The children mostly stated that their feelings and thoughts 
are not taken seriously, they are mocked, humiliated or rejected. That is, the children stated that they are most emotionally abused by their friends, followed by strangers, family members "brother, sister, mother, father" and relatives "aunt, uncle".

Table 6. Distribution of the Strategies Used to Cope with Abuse According to Gender and Grade Level

\begin{tabular}{lllllll}
\hline & \multicolumn{3}{c}{ GIRLS } & \multicolumn{3}{c}{ BOYS } \\
\cline { 2 - 7 } Grade Level & $\begin{array}{l}\text { Active- } \\
\text { cognitive (f) }\end{array}$ & $\begin{array}{l}\text { Active- } \\
\text { behavioral (f) }\end{array}$ & $\begin{array}{l}\text { Avoidant } \\
\text { (f) }\end{array}$ & $\begin{array}{l}\text { Active- } \\
\text { cognitive (f) }\end{array}$ & $\begin{array}{l}\text { Active- } \\
\text { behavioral (f) }\end{array}$ & $\begin{array}{l}\text { Avoidant } \\
\text { (f) }\end{array}$ \\
\hline $5^{\text {th }}$ Grade & 0 & 15 & 11 & 8 & 16 & 3 \\
$6^{\text {th }}$ Grade & 1 & 17 & 10 & 0 & 14 & 9 \\
$7^{\text {th }}$ Grade & 3 & 18 & 13 & 2 & 17 & 8 \\
$8^{\text {th }}$ Grade & 3 & 15 & 8 & 1 & 25 & 7 \\
Total & 7 & 65 & 42 & 11 & 72 & 27 \\
\hline
\end{tabular}

The children were asked the question "What do you do when you are maltreated?" to determine the coping strategies they prefer more in the case of abuse. They children's responses were analyzed by classifying them into the categories of active-cognitive, active-behavioral and avoidant. As can be seen in Table 6, the children prefer active-behavioral strategies more than the others in the face of a problem situation. However, the number of the children preferring the avoidant strategies and to act as if there was nothing instead of seeking for a solution to the problem is highly remarkable. The girls seem to prefer the avoidant strategies than the boys. Some of the children's responses to this question are directly quoted below. The letter in the parenthesis (B or G) stands for the gender of the child and the number next to it represents the code of the child.

Active-cognitive strategies: "I ask the opinions of adults "(B6), "I think about anything 3 times",(B8), "I try to reach a comprise with him/her"(G39), "I try to get out of the situation"(G58), "I try to calm down"(G68)

Active-behavioral strategies: "I talk to my family, friends, teacher" (G13), "I immediately go to my elders “(B3), "I warn that person" (B6), "I call the police” (B18), "I beat the person treating me badly" (B25), "I respond to them as they did"(G56).

Avoidant strategies: "I go to my room and cry" (G10), "I feel shy" (G5), "I do not tell anyone" (G1), "I stand still” (G22), "I try to be patient as long as possible"(B34), "I never talk to him/her again"(G24), "I refer him/her to the God's punishment" (B43), "I take the line of the least resistance" (B53), "I immediately walk away" (B67), "I keep it to myself" (G72).

\section{Conclusion and Recommendations}

According to the results of the current study, $79 \%$ of the 616 children in the age groups of $7,8,9,10,11,12,13$ and 14 attending elementary and secondary schools stated that they had been exposed to abuse. In the evaluation made to determine which age groups are under the risk of being abused revealed no significant difference across the age groups. Of the children from different age groups 70-75\% stated that they had been exposed to abuse. These results are show that children of any age can be victims of abuse. It is estimated that each year 1.6 million children are abused or neglected. When different studies are examined, it is seen that $30 \%$ of the abused children are in the age group of $2-5,40 \%$ are in the age group of $6-10,30 \%$ are in the age group of $11-17$. In another words, $70 \%$ of the victims are children in younger age groups. These data are taken from judicial units (Kocabiy1k, 2018). When the cases of abuse and neglect are examined according to gender, it is seen that $73 \%$ of the girls and $47 \%$ of the boys have been exposed to any type of abuse. Çeçen (2007) identified that girls are more abused than boys in Turkey and the world. According to the report of child protective service agencies in the United States during 2016, 51\% of the child victims were girls, and 48.6 percent were boys. The gender was unknown for 0.4 percent of victims.

When the behaviors seen as the expression of love and ways of showing love to children are examined, both girls and boys stated that emotional feedbacks are used most frequently to show them that they are loved. The children also stated that physical feedbacks such as "hugging, kissing or touching on the body" can be expressions of love. Especially in Turkish culture, the way that people other than parents and close relatives show love to children is often in the form of hugging, kissing or touching their body. In settlements where the old traditions still exist, it is normal for a child to be loved through physical contact by people who don't know the child. This increases likelihood for children to be physically and sexually abused because the child and even the parent cannot distinguish between acts of love and abuse. Within this scope, there are more attempts and studies to inform people about abuse related 
issues, but there still some small societies that these attempts did not reach them yet.

The ways that are used to love the child are very important for the child to perceive their own physical limits and to distinguish the behaviors that are considered to be abusive. In a study conducted by the World Health was found that $23 \%$ of the children had physical abuse, $36 \%$ emotional abuse, $16 \%$ physical neglect and $26 \%$ sexual abuse Worldwide (WHO, 2017). Parallel to these results, UNICEF (2010) conducted a study on child abuse and domestic violence in Turkey and reported that $51 \%$ of the children in the age group of 7-18 are emotionally abused and $43 \%$ of them are physically abused and 3\% of them are sexually abused (Bakır \& Kapucu, 2017; Korkmazlar Oral, Engin \& Büyükyazıc1, 2010). In a study conducted on children in our country, it was found that children are more physically abused than in other countries, probably because beating has been used as an educational tool. Emotional abuse is thought to be associated with social and cultural structure. Thus, an attitude that can be considered to be an abuse or neglect in one culture can be a normal part of another culture (Dinleyici \& Şahin Dağl1, 2016; Glasser, 2002). When we look at the parenting, child rearing and child care practices of different cultures, it is seen that they occasionally exhibit many attitudes destructive on the child without knowing that there is actual abuse.

Child abuse is defined as the application of a non-accidental, preventable, deliberate behavior that adversely affects physical, emotional, mental or social development of the child by an adult, the society, the state or another child. When the people responsible for different types of act of abuse directed to the child were examined within the context of the current study, it was found that the children from both genders and all the age groups were most abused by their peers, followed by family members and relatives. The children mostly stated that their feelings and thoughts are not taken seriously; they are mocked, humiliated or physically abused by their friends, family members and relatives. In a study conducted by UNICEF in 2010, they explained that the abusers were father, teacher, mother, friend and neighbor, respectively. In addition, many children of all ages stated that they were exposed to maltreatments of school or neighborhood friends. According to the results of similar studies, it was found that $77 \%$ of the responsible individuals for all types of abuse are family members, $11 \%$ are other relatives, $5 \%$ are not connected with the care of the child and $2 \%$ are other caregivers. It is known that $60 \%-70 \%$ of cases of sexual abuse are carried out by people who are known and trusted by the child, such as parents, relatives, teachers, neighbors or authority figures (Taner \& Gökler, 2004; Jain, 1999, Kara et al., 2004; Çeçen, 2007). Therefore, children may never tell anyone that they are exposed to abuse. If the family never suspects the situation, then the case of abuse may go unnoticed; between 1985 and 1989, 79\% of 630 cases of sexual abuse first denied abuse or hesitated to openly state it, $3 / 4$ of them accidently made an explanation and $22 \%$ of them withdrew their explanation (Everstine \& Everstine, 1989).

The children were asked to answer "What do you do when you are maltreated?" to determine the coping strategies they prefer more in the case of abuse and their responses were analyzed by classifying them into the categories of active-cognitive, active-behavioral and avoidant. According to the results of the study was found that the children prefer active-behavioral strategies more than the other strategies in the face of abuse. Uysal et al. (2017) investigated the coping strategies used by children in problem situations and their results were similar to the results of the current study and in general as they also determined that the children prefer active-behavioral strategies more than other strategies in the face of problem. When the gender variable is taken into consideration, it is seen that girls use the avoidance strategies more than boys. As a result, it is seen that the basics of coping strategies used by the children are laid in early childhood and that problem solving methods do not change in the following years. Therefore, informing children about abuse should be initiated as early as possible in accordance with the age and developmental level of the child. As children are very frequently abused by their peers, this process should first start with informing children about healthy friendship relationships. Parents should also be informed about how to establish healthy communication with their children. Moreover, through media and public trainings, families' awareness of abuse should be raised. Parent and caregiver support to teach parents about child development and healthy positive strategies for raising children. Promoting norms and values that support pro-social, non-violent behavior is important. Creating and sustaining safe environments for children. Implementation and enforcement of laws, such as laws banning violent punishment of children by parents, teachers or other caregivers. Response and support services to help children that have been exposed to violence (WHO, 2017). Visiting homes of children who are suspected of being abused, psychosocial education of the parent, improving the home environment and making necessary notifications without delay for the protection of the child reduces the likelihood of abuse (Dinleyici \& Şahin Dağlı, 2016; Lee et al., 2018). Even if family trainings are important to protect children against emotional, physical and sexual abuse, the most effective method of protecting them is raising their self-awareness of abuse. Elliott, Browne and Kilcoyne (1995) stated that if children's can be taught how to reject, resist or saying "no" when faced with improper requests, then they can protect themselves against sexual abuse. 
For this reason, children should be educated about what should be kept as a secret. If the hidden facts are causing harm to someone or to themselves, if they hurt them and make them frightened, then they should not be kept a secret and should be shared with someone trusted. In addition, when the child is faced with inappropriate requests, the awareness of the necessity of saying "no" should be taught to the child. In order to protect the child against sexual abuse, they should be given the message that they can easily ask their parents and teacher about whatever sexual issue they are interested in. Parents should be informed about the needs of the child's sexual development and how to deal with their sexual interests in a proper and healthy way.

When we consider that children are mostly abused by their peers, it is necessary to inform and raise awareness about how conflicts come out between them and adolescents, how to act during these conflicts, and possible consequences of these conflicts. Yavuzer, Karataş, and Gündoğdu (2013) revealed that especially $10^{\text {th }}$ and $11^{\text {th }}$ grade boys apply problem solving skills based on aggression, and disagreements between them can frequently turn into aggression and abuse. In that sense, education of health communication should be provided to children, and this education should be kept until their communication styles change in a desired way.

\section{References}

Aydın, B., \& İmamoğlu, Ü. S. (2001). Stresle Başaçıkma Becerisi Geliştirmeye Yönelik Grup Çalışması. Atatürk Ĕgitim Fakültesi Eğitim Bilimleri Dergisi, 14, 41-52.

Bakır, E., \& Kapucu, S. (2017). Çocuk İhmali Ve İstismarının Türkiye'de Yapılan Araştırmalara Yansıması: Bir Literatür İncelemesi. Hacettepe Üniversitesi Hemşirelik Fakültesi Dergisi, 4(2), 13-24.

Burger, J. M. (2006). Kişilik Psikoloji Biliminin İnsan Doğasına Dair Söyledikleri. Çev: İnan Deniz Erguvan Sarıoglu. İstanbul: Kaknüs Yayınları.

Çeçen, A R. (2007). Çocuk Cinsel İstismarı: Sıklığı, Etkileri ve Okul Temelli Önleme Yolları. Uluslararası İnsan Bilimleri Dergisi, 4(1), 2-17.

Child Welfare Information Gateway. (2013). What Is Child Abuse And Neglect? Recognizing The Signs And Symptoms. Retrieved from https://www.childwelfare.gov/pubpdfs/whatiscan.pdf

Crosson-Tower, C. (1993). Understanding Child Abuse and Neglect. National Academies Press.

Dinleyici, M., \& Şahin Dağlı, F. (2016). Duygusal İhmal, İstismar ve Çocuk Hekiminin Rolü. Osmangazi Tip Dergisi, 38(2), 18-27.

Elliott, M., Browne, K., \& Kilcoyne, J. (1995). Child sexual abuse prevention: What offenders tell us. Child Abuse \& Neglect, 19(5), 579-594. https://doi.org/10.1016/0145-2134(95)00017-3

Everstine, D.S., \& Everstine, L. (1989). Sexual Trauma In Children And Adolescents: Dynamics And Treatment. New York: Brunner/Mazel.

Glaser, D. (2002). Emotional abuse and neglect (psychological maltreatment): A conceptual framework. Child Abuse \& Neglect, 26(6), 697-714. https://doi.org/10.1016/S0145-2134(02)00342-3

Hart, H., \& Rubia, K. (2012). Neuroimaging of child abuse: a critical review. Frontiers in Human Neuroscience, 6(52), 1-24. https://doi.org/10.3389/fnhum.2012.00052

Kara, B., Biçer, Ü., \& Gökalp, AS. (2004). Çocuk İstismarı. Çocuk Sağllğı Ve Hastalıkları Dergisi, 47, 140-151.

Karaca, K. (2018). Çocuk Ihmali Ve İstismarı. Ankara: Eğitim Ve Bilim Emekçileri Sendikası Yayını.

Kocabıyık, S. (2018). Çocuk Cinsel İstismarı Ve Zor Açı̆̆a Çıkması Bilgilendirme Dosyası. Retrieved from http://www.psikiyatri.org.tr/uploadfiles/219201618057

Korkmazlar Oral, Ü., Engin, P., \& Büyükyazıcı, Z. (2010). Türkiye'de Çocuk İstismarı Ve Aile İçi Şiddet Araş̧trmasi/Özet Rapor. Retrieved from http://www.unicef.org.tr/files/bilgimerkezi/doc/cocuk-istismari-raporu-tr.pdf

Leea, E., Kirklandb, K., Miranda-Julianb, C., \& Greenec, R. (2018). Reducing Maltreatment Recurrence Through Home Visitation: A Promising İntervention For Child Welfare İnvolved Families. Child Abuse \& Neglect, 86, 55-66. https://doi.org/10.1016/j.chiabu.2018.09.004

Mavi Aydoğdu, S.G., \& Özsoy, Ü. (2017). Çocuk Kötü Muamelesinin Ve Sonuçlarının Bilimsel Olarak İncelenmesi. Hemşirelik Akademik Araştırma Dergisi, 3, 57-60. 
U.S. Department of Health \& Human Services, Administration for Children and Families, Administration on Children, Youth and Families, Children's Bureau. (2018). Child maltreatment 2016. Retrieved from https://www.acf.hhs.gov/cb/research-data-technology/statistics-research/child-maltreatment.

World Health Organization. (2017). Child Maltreatment, The Health Sector Responds. Retrieved from http://www.who.int/violence_injury_prevention/violence/child/Child_maltreatment_infographic_EN.pdf

World Report On Violence And Health. (2018). Child Abuse and Neglect by Parents and Other Caregivers. Retrieved from http://www.who.int/violence_injury_prevention/violence/global_campaign/en/chap3.p9

Yavuzer, Y., Karataş, Z., \& Gündoğdu, R. (2013). Ergenlerin çatışma çözme davranışlarının incelenmesi: nicel ve nitel bir çalışma. Hacettepe Üniversitesi Eğitim Fakültesi Dergisi, 28(1), 428-440. 